\title{
Integrated approach across prerequisite programmes and procedures based on HACCP principles
}

\author{
AGNIESZKA JACKOWSKA-TRACZ, MICHAŁ TRACZ, KRZYSZTOF ANUSZ \\ Department of Food Hygiene and Public Health Protection, Faculty of Veterinary Medicine, \\ Warsaw University of Life Sciences - SGGW, Nowoursynowska 159, 02-776 Warsaw, Poland
}

Jackowska-Tracz A., Tracz M., Anusz K.

Integrated approach across prerequisite programmes and procedures based on HACCP principles

Summary

Food business operators are required to implement and maintain a system based on HACCP principles. The HACCP is the only food safety management system, the implementation of which is obligatory. The standards laid down by the Codex Alimentarius Commission serve as benchmarks not only for the obligatory implementation of the HACCP system principles, but also for private standards such as ISO, IFS or BRC. A voluntary implementation of private standards may lead to the wrong assumption that food companies do not necessarily have to but only may comply with the guidelines laid down by the implemented standard. The HACCP system guarantees no absolute food safety in and of itself. The underlying assumption of the HACCP system is that high-risk hazards should be controlled with the use of critical control points (CCPs). It is impossible to identify CCPs in all enterprises. In certain food businesses there are exclusively medium-risk or low-risk hazards that may be controlled with oPRPs or PRPs, respectively. The awareness on the role of critical control points and prerequisite programmes in the producer's efforts to prevent or eliminate hazards, or to reduce them to acceptable levels, is a key for performing a comprehensive supervision. During the performance of an official control, instead of focusing exclusively on the HACCP procedures, it is reasonable to apply an integrated approach comprising both prerequisite programmes and the HACCP principles.

Keywords: hazard, HACCP system, CCP, oPRP, PRP

The private systems for ensuring food safety are closely linked to the increasing globalisation of food production processes. The consequence of the above is the development of organisations responsible for the control (global, local, government and private organizations) and the establishment of certain legal regulations (public law and private law). The implementation of quality systems, including non-obligatory ones, is considered to be a fundamental prerequisite for the operation of enterprises on the global food market.

The HACCP (Hazard Analysis and Critical Control Point) system is the only food safety management system the implementation of which is obligatory, which means that its implementation is directly required by the provisions of food law. As it follows from Regulation (EC) No. 852/2004 of the European Parliament and of the Council of 29 April 2004 on the hygiene of foodstuffs, ,the food business operators should establish and operate food safety programmes and procedures based on the HACCP principles" (15). The principles of the HACCP system are described in the CAC/RCP 1-1969 „General Principles



Fig. 1. Principles of the HACCP system according to the Codex Alimentarius

of Food Hygiene" standard developed by the Codex Alimentarius Commission (CAC), hereafter referred to as the Codex Alimentarius (4) (Fig. 1). The Codex Alimentarius Commission, established by two United Nations agencies, i.e. the Food and Agriculture Organisation (FAO) and the World Health Organisation (WHO), has already developed hundreds of standards, including over 200 food-related standards, which makes it an institution of global reach. The standards 
laid down by the Codex Alimentarius Commission serve as benchmarks not only for the obligatory implementation of the HACCP system principles, but also for private standards such as ISO 22000 -Food Safety Management, International Featured Standard (IFS; previously known as the International Food Standard), or the British Retail Consortium (BRC).

\section{HACCP System According to the Codex Alimentarius Standards}

The HACCP system has been designated to identify, evaluate and control any hazards that are crucial for ensuring food safety (4). Initially, it comprised exclusively of microbiological hazards and was later extended to include also physical and chemical hazards. For the time being, some experts believe that allergens constitute a separate category of hazards. The HACCP system has been designed to minimise the risk of food safety hazards. However, it is not a zero-risk system (18). The HACCP system helps entrepreneurs identify and control hazards occurring in a given processing plant - an approach that is based on the hazard analysis performed separately for each production stage - the system, however, guarantees no absolute food safety in and of itself. The HACCP system must be subject to continuous improvement and enhancement. It should be considered rather as a specific procedure to be adopted than a certain programme for one-off implementation. The documentation of the HACCP system should be as simple and easy to apply as possible. There are instances where the system becomes too complicated and, consequently, useless due to the lack of proper knowledge among the HACCP team members. The idea that inspired the authors was to create a minimalist system that would provide for a maximum control $(1,17)$ by shifting the focus from reaction to prevention $(7)$.

The underlying assumption of the HACCP system is that high-risk hazards should be controlled with the use of critical control points (CCPs). At the same time, it should be noted that it is impossible to identify critical control points in all enterprises, which has already been emphasised in Recital 15 of Regulation (EC) no. 852/2004 on the hygiene of foodstuffs (15). For instance, there are no typical critical control points, such as heat treatment, in a slaughterhouse (19). In certain food businesses there are exclusively medium-risk or low-risk hazards that may be controlled with oPRPs or PRPs, respectively (5).

The HACCP plan, which is based on the Codex Alimentarius, covers the following points: 1) product description; 2) process flowchart; 3) hazard analysis; 4) designation of critical control points; 5) CCP monitoring and corrective measures; 6) system verification; and 7) documentation. The principle which is essential for the correct implementation and operation of the HACCP system is the performance of a hazard analysis (3). An erroneous or a non-complex hazard analysis has repercussions for further stages of system implementation and may lead to hindrances or even the impossibility of its orderly functioning - the system becomes dead and is not really operational (20). Under the HACCP system, the hazard analysis is performed for stagespecific hazards, i.e. hazards arising from a specific production stage (10). For instance, the curing stage requires an analysis of a chemical hazard, which is an exceedingly high dosage of a curing mix. The abovedescribed hazard occurs only at this particular stage (curing), which means that it is a stage-specific hazard. There are also non-stage specific hazards in processing plants; for instance, the microbiological hazards resulting from the application of contaminated equipment or the use of poor quality water. Such hazards may occur at different production stages, in any and all places where contaminated instruments are applied or poor quality water is used, which means that they are non-stage specific hazards. The non-stage specific hazards are usually controlled with the application of the principles of Good Manufacturing Practices (GMP) and Good Hygiene Practices (GHP). The GMP and GHP programmes lay down the preliminary conditions that must be fulfilled prior to the implementation of the obligatory HACCP system by an enterprise. The GMP/GHP requirements apply to the environment, premises, transportation, equipment, production organisation, warehouse management, water and sewage management and waste management, as well as DDD measures and staff requirements (15).

\section{The Scope of Hazard Analysis in Food Processing Establishments According to Codex Alimentarius (HACCP) Standards and Requirements of Private Food Safety Management Systems}

The HACCP system has been developed to ensure the health quality of products. Given that food safety problems and issues related to broadly understood quality cannot be discussed separately, many food processing plants implement additional non-obligatory quality assurance standards that are also referred to as private food law. These systems make it possible to ensure not only health quality but also quality from the perspective of a recipient (business partner) and consumer, i.e. also commercial, nutritional and organisational quality. Such an example is the Integrated Quality and Food Safety Management System, implemented and certified in accordance with the requirements laid down by ISO 9001: Quality Management System and ISO 22000: Food Safety Management Systems - Requirements for any organization in the food chain.

In recent years, more and more food producers have decided to implement one, several or even more than a dozen quality management standards of different kinds. The structure and the scope of requirements set by these standards are often similar. The implementation of multiple standards ensures the recognition of the quality of products offered by a given food producer 
and constitutes a part of their commercial offer or satisfies consumer requirements, which is the highest priority for any entrepreneur. The list of private standards relating to food safety is very long. ISO, IFS and BRC belong to the most widely recognised standards on the global market, while the youngest one among all major private systems relating to food safety is ISO 22000 (11).

The IFS standard, which was established by the representatives of the German and French food trade industry over the period 2002-2003, refers to the Global Food Safety Initiative (GFSI) and addresses all its requirements concerning quality and risk management to all food producing companies. The implementation of the BRC standard is tantamount to the certification of conformity with the British Retail Consortium standard, which is recognised by the GFSI. There are also special requirements concerning any standards developed for the purpose of ensuring food safety in airline catering, which is currently supervised by the Veterinary Inspection or the State Sanitary Inspection, depending on a given region of Poland. The ICQA standard (IATA Catering Quality Assurance Programme) has been developed and is recommended by the International Air Transport Association (IATA), the mission of which is the establishment of general standards applying to civil aviation, including the determination of standards for all production stages of foodstuffs that are to be served on board. Furthermore, IATA supports food producers by publishing interpretative guidelines on risk management (8).

In practice, the implementation of the ISO 22000: Food Safety Management Systems - Requirements for any organisation in the food chain is tantamount to a consent to undergo a HACCP certification audit carried out by one of many certification bodies operating on the market. The ISO 22000 standard is also referred to as the certified HACCP system in the colloquial language. Although the implementation of the HACCP system is obligatory, its certification is voluntary. The ISO 22000 standard includes requirements for each organisation operating directly or indirectly at one or several stages of a food chain, regardless of its size and diversity. Not only does the above refer to food producers, but also to distributors (warehouses, wholesalers), machinery and equipment manufacturers, catering companies, traders, hotels, transportation companies, packaging manufacturers, etc. The prevailing feature of the ISO 22000 standard is that it brings together the HACCP system (the HACCP principles based on the Codex Alimentarius) and the prerequisite programmes (PRPs) (1), whereby the afore-mentioned prerequisite programmes include all good practices applicable in a given company, for instance: GMP, GHP, GCP (Good Catering Practice), GAP (Good Agricultural Practice), GVP (Good Veterinary Practice), GPP (Good Production Practice), GDP (Good Distribution Practice) and GTP (Good Trading Practice). The implementation of the ISO 22000 standard implies the extension of the scope of a hazard analysis. Under the HACCP system based on the Codex Alimentarius, it is necessary to carry out hazard analyses exclusively for stage-specific hazards. Meanwhile, the certification of the HACCP system for conformity with ISO 22000 standard requires the performance of hazard analyses also for non-stage specific hazards; that is for any hazards discussed within prerequisite programmes (PRPs). The performance of a hazard analysis for the purposes of prerequisite programmes (PRPs) may result in the designation of operational prerequisite programmes (oPRPs). Both critical control points and operational prerequisite programmes are designated if there are any safety measures necessary to control a specific hazard. The critical control points are designated at the stage where it is necessary to control the hazard to eliminate the risk of food safety or reduce it to acceptable levels (risk critical to health). The operational prerequisite programmes (oPRPs) are designated with reference to a product or process environment as the basic component of managing the likelihood of the introduction of food safety hazards. An example of a critical control point may be a cooking stage in the production of a cooked ham (the monitoring of parameters of a ham heat treatment process), whereas an example of an operational prerequisite programme may be the cold storage of a finished product (the monitoring of air temperature in a cold store). The awareness of the role of critical control points and prerequisite programmes in the producer's efforts to prevent or eliminate hazards, or to reduce them to acceptable levels, is a key for performing a comprehensive inspection by the veterinarians who are responsible for the supervision over plants where the food of animal origin is processed.

\section{Aligning HACCP Principles with Requirements of Private Food Safety Management Systems and Their Impact on Hazard Analysis in Food Processing Establishments}

The situation in which food businesses implement non-mandatory food safety management systems gives rise to increasing uncertainty on the part of official veterinarians regarding the extent of official controls over plants that have already implemented systems that form part of private food law.

This uncertainty results from two facts. First, private standards often apply modified nomenclature with reference to the components of systems, principles and criteria adopted in the European Union and national legislation. It should be noted that the above fact does not indicate their non-conformity, as they originate from and are based on the same foundations as the European Union and national legislation, i.e. on the requirements specified by the Codex Alimentarius Commission. Second, private standards frequently impose higher or new requirements towards market entities, which differ from the provisions of generally 
applicable law. Any additional requirements may apply, among others, to production parameters, processing conditions, microbiological criteria and the product itself, as well as a wider scope of their application. By way of illustration, there are currently no limits set for Campylobacter jejuni in the regulation on the microbiological criteria for foodstuffs (14), while such criteria may be found in other private standards and are usually very restrictive: the current limit is for this bacterium to be absent in $25 \mathrm{~g}$ of a product $(9,13)$. The question therefore arises whether an official veterinarian may control the conformity of the performance of activities planned under the provisions of voluntarily implemented standards or whether they may control only the correctness of activities resulting from the generally applicable provisions of law. A voluntary implementation of private standards may lead to a wrong assumption that food companies do not necessarily have to but only may comply with the guidelines laid down by the implemented standard and that official veterinarians have no legal basis to request the achievement of assumptions concerning the implementation of a specific standard. Any control measures, methods and techniques applied during official controls are described in Article 10 of the Regulation (EC) No. 882/2004 of the European Parliament and of the Council of 29 April 2004 on official controls performed to ensure the verification of compliance with feed and food law, animal health and animal welfare rules. Among the first activities undertaken as part of official controls is the ,examination of any control systems that feed and food business operators have put in place and the results obtained" (16). There is no differentiation of the systems implemented in an specific plant between those based on the provisions of generally applicable law and those based on the provisions of private food law, i.e. voluntary systems, in Article 10 of the above Regulation. Furthermore, Article 10 contains the guidelines concerning the examination of any and all systems implemented in the plant, irrespective of the legal basis for their implementation. One method for performing an official control provided for in Article 10 is an official audit, which is defined as ,a systematic and independent examination to determine whether activities and related results comply with planned arrangements and whether these arrangements are implemented effectively and are suitable to achieve objectives". In that case, the official veterinarian examines the activities, results and effectiveness of the implemented solutions during the performed audit, regardless of the fact whether they have a legal basis in the provisions of generally acceptable law or the provisions of private law.

It should be noted that the results of a hazard analysis performed for a given enterprise, in which a specific standard has been implemented and is maintained, may differ from the results of a hazard analysis performed for the same enterprise without considering any activi- ties that have a legal basis in private standards. In practice, these differences may be observed, among others, in the number of established critical control points (CCP). In fact, these enterprises that implement private food safety management standards extend and improve the already existing, obligatory HACCP system. One of the basic requirements towards food companies set by private systems is that they must satisfy any and all provisions of the generally applicable law adopted in the producer's country and on the target market (12). Thus, the requirement related to the obligatory implementation of HACCP system principles resulting from the Regulation (EC) No. 852/2004 forms an integral part of private systems, such as ISO, BRC and IFS. It is, therefore, impossible to separate only the „HACCP book" for the purposes of an official control in these establishments that have implemented other additional private standards. Let us reflect on a hypothetical transformation of a plant from the HACCP system, based on the Codex Alimentarius, to ISO 22000 standard (Fig. 2). The food processing establishment has implemented procedures based on the principles of the obligatory HACCP system. A hazard analysis resulted in the identification of five critical control points (CCPs) on the following stages: raw material acceptance - CCP1, heat treatment - CCP2, cooling - CCP3, modified atmosphere packaging - CCP4 and cold storage- CCP5. After the system transformation, i.e. after the implementation of the ISO 22000 standard, only two critical control points (CCP) have remained in the establishment, i.e. heat treatment - CCP1 and cooling - CCP2. If the official control referred only to critical control points in this establishment, it could be argued that the extent of control is considerably smaller following transformation. However, it should be considered that the remaining critical control points in the above discussed example have not been eliminated, but they have been identified as oPRPs that should also be subject to control. In the end, it could be stated that identical hazards continue to be controlled, but with

\begin{tabular}{|c|c|c|}
\hline $\begin{array}{c}\text { Technological } \\
\text { scheme }\end{array}$ & $\begin{array}{c}\text { HACCP } \\
\text { CCP }\end{array}$ & $\begin{array}{c}\text { ISO 22000 } \\
\text { CCP/oPRP }\end{array}$ \\
\hline Stage 1 & CCP 1 & oPRP \\
\hline Stage 2 & & \\
\hline Stage 3 & & CCP 1 \\
\hline Stage 4 & CCP 2 & CCP 2 \\
\hline Stage 5 & CCP 3 & \\
\hline Stage 6 & & oPRP \\
\hline Stage 7 & CCP 4 & \\
\hline Stage 8 & & oPRP \\
\hline Stage (12) & CCP 5 & \\
\hline
\end{tabular}

Fig. 2. The comparison of CCPs designated in an exemplary food processing establishment under the HACCP system and CCPs designated after the transformation of the system to the ISO 22000 standard (after (1)) 
an indication that enforcing compliance at the stage of raw material acceptance, cooling and modified atmosphere $\mathrm{pack}$ a g ing is carried out through the oPRPs.

Private standards form an integral part of the implemented procedures, while the assessment of the fulfilment of ownership obligation to ensure the safety of produced food is possible based on a comprehensive analysis of any and all planned arrangements. During the performance of an official control, instead of focusing exclusively on the HACCP procedures, it is reasonable to apply an integrated approach comprising both prerequisite programmes and the HACCP principles (Fig. 3). In this respect, the HACCP system is not synonymous with food safety (19). It is one of many tools applied within the food safety management system $(6,17)$.

\section{References}

1. Arvanitoyannis I., Kassaveti A.: HACCP and ISO 22000 - a comparison of the two systems, [in:] Arvanitoyannis I. S. (ed.): HACCP and ISO 22000. Application to Foods of Animal Origin. Blackwell Publishing Ltd, Oxford 2009 , p. 3-45.

2. Arvanitoyannis I. S., Varzakas T. H., Tserkezou P.: Maeat and Meat Products, [in:] Arvanitoyannis I. S. (ed.): HACCP and ISO 22000. Application to Foods of Animal Origin. Blackwell Publishing Ltd, Oxford 2009, p. 181-276.

3. Cerf O., Donnat E.: Application of hazard analysis - critical control point (HACCP) principles to primary production: what is feasible and desirable? Food Control 2011, 22, 1839-1843.

4. Codex Alimentarius Commission: General Principles of Food Hygiene, CAC/ RCP 1-1969, Rev. 4 - 2003.

5. European Commission: Commission Notice on the implementation of food safety management systems covering prerequisite programs (PRPs) and procedures based on the HACCP principles, including the facilitation/flexibility of the implementation in certain food businesses, 2016. Off. J. Europ. Union 2016/C 278/01.

6. Herrera A. G.: The hazard analysis and critical control point system in food safety. Methods Mol. Biol. 2004, 268, 235-280.

7. Hulebak K. L., Schlosser W.: Hazard analysis and critical control point (HACCP) history and conceptual overview. Risk Anal. 2002, 22, 547-552.

8. ICQA - IATA Catering Quality Assurance Programme. Food Processing Safety Standards and Interpretation Guidelines. Medina Foods Inc. 2008, $2^{\text {nd }}$ version.

9. IFSA and AEA World Food Safety Guidelines, $2^{\text {nd }}$ version, 2007.

10. Kwiatek K., Osiński Z.: Analiza zagrożeń i analiza ryzyka w łańcuchu żywnościowym w świetle norm Kodeksu Żywnościowego - dorobek i perspektywy. Rola Komisji Kodeksu Żywnościowego FAO/WHO w zapewnieniu bezpieczeństwa i jakości żywności oraz uczciwych praktyk w międzynarodowym handlu żywnością. Warszawa 2014. http://www.piwet. pulawy.pl/piwet7/newslet/-2010-03/opr_ref/opr_ref_2.pdf

11. Meulen B. van der: Private food law. The emergence of a concept, [in:] van der Meulen B. (ed.): Private Food Law. Governing food chains through contract law, self-regulation, private standards, audits and certification schemes. Wageningen Academic Publishers, Wageningen 2008, p. 29-50.
12. Meulen B. van der: The anatomy of private food law, [in:] van der Meulen B. (ed.): Private food law. Governing food chains through contract law, selfregulation, private standards, audits and certification schemes. Wageningen Academic Publishers, Wageningen 2008, p. 75-108.

13. QSAI - Catering Quality Assurance Programme. Food Processing Safety Standards and Interpretation Guidelines. Medina Foods Inc. 2011, $4^{\text {th }}$ version.

14. Regulation (EC) No. 2073/2005 of 15 November 2005 on microbiological criteria for foodstuffs, Official Journal of the European Union L 338/1 of 22 December 2015, as amended.

15. Regulation (EC) No. 852/2004 of the European Parliament and of the Council of 29 April 2004 on the hygiene of foodstuffs. Off. J. Europ. Union L 139/1 of 30 April 2004, as amended.

16. Regulation (EC) No. 882/2004 of the European Parliament and of the Council of 29 April 2004 on official controls performed to ensure the verification of compliance with feed and food law, animal health and animal welfare rules, Off. J. Europ. L 165/1 of 30 April 2004, as amended.

17. Rushing J. E., Ward D. R.: HACCP Principles. Food Safety FSE. N.C. State University 1999, p. 99-121. https://www.ces.ncsu.edu/depts/foodsci/ext/pubs/ haccpprinciples.pdf

18. Shan Y.: Quality and safety control during citrus processing, [in:] Shan Y. (ed.): Canned Citrus Processing: Techniques, Equipment, and Food Safety. Academic Press, Amsterdam 2016, p. 105-150.

19. Sperber W. H.: HACCP and transparency. Food Control 2005, 16, 505-509.

20. Wallace C. A., Holyoak L., Powell S. C., Dykes F. C.: HACCP - the difficulty with hazard analysis. Food Control 2014, 35, 233-240.

Corresponding author: Agnieszka Jackowska-Tracz, DVM, PhD, Nowoursynowska 159, 02-776 Warsaw, Poland; e-mail: agnieszka_jackowska_ tracz@sggw.pl 